\title{
Role of Chymase-Dependent Angiotensin II Formation in Monocrotaline-Induced Pulmonary Hypertensive Rats
}

\author{
KANTA KISHI, DENAN JIN, SHINJI TAKAI, MICHIKO MURAMATSU, HIROSHI KATAYAMA, HIROSHI TAMAI, AND \\ MIZUO MIYAZAKI \\ Department of Pharmacology [K.K., D.J., S.T., M.Mu., M.Mi.], Department of Pediatrics [H.K., H.T.], Osaka Medical College, \\ 2-7 Daigaku-machi, Takatsuki City, Osaka 569-8686, Japan
}

\begin{abstract}
Angiotensin II-forming chymase is expressed in the pulmonary arteries of the monocrotaline-induced pulmonary hypertensive rats, but its actual role is unclear. We studied chymasedependent angiotensin II formation in the pulmonary arteries of the monocrotaline-induced pulmonary hypertensive rats and observed the effects of an angiotensin II receptor blocker on vascular remodeling. Four weeks after the administration of monocrotaline (60 mg/kg, s.q.), echocardiographic, hemodynamic, morphometric and biochemical analyses were performed. Age-matched rats were used as controls. To evaluate the effects of an angiotensin II receptor blocker, 2 wk after beginning of monocrotaline treatment, the rats were given candesartan $(10 \mathrm{mg} / \mathrm{kg}$ per day) or placebo for $2 \mathrm{wk}$. In the monocrotaline-induced pulmonary hypertensive rats, the elevated systolic pulmonary arterial pressure and right ventricular hypertrophy were observed. Medial hypertrophy of lung arterioles was also observed. Chymase activity and angiotensin II concentration, but not angiotensin-converting enzyme activity, were significantly increased in the lung. In the angiotensin II receptor blocker-treated group, both systolic pulmonary arterial pressure and right ventricular hypertrophy were significantly reduced, and arteriolar hypertrophy was also prevented. Thus, angiotensin II-forming chymase may play a role in the proliferation of the medial layer in the lung arterioles of monocrotaline-induced pulmonary hypertensive rats. (Pediatr Res 60: 77-82, 2006)
\end{abstract}

$\mathrm{C}$ hymase is a chymotrypsin-like serine protease that is thought to be present in the secretory granules of mast cells. Chymase is able to cleave the bonds of angiotensin I between phenylalanine and histidine $(1,2)$. Chymase purified from human cardiovascular tissues easily converts angiotensin I to angiotensin II $(1,2)$, and chymase-dependent angiotensin II may have a role in human cardiovascular tissue function. For example, in human heart extracts, over $75 \%$ of total angiotensin II-forming activity depended on chymase, and the remaining depended on angiotensin-converting enzyme (ACE) (1). In human vascular tissue extracts, about $90 \%$ of total angiotensin II-forming activity was inhibited by a chymase inhibitor, and the remaining activity was inhibited by an ACE inhibitor (3). These findings suggest that chymase pri-

Received November 15, 2005; accepted February 28, 2006.

Correspondence: Shinji Takai, Ph.D., Department of Pharmacology, Osaka Medical College, 2-7 Daigaku-machi, Takatsuki City, Osaka 569-8686, Japan; E-mail: pha010@art.osaka-med.ac.jp

This work was partly supported by a grant (16659068) from the Japanese Ministry of Education, Science, Sports, and Culture.

DOI: 10.1203/01.pdr.0000219431.45075.d9 marily produces angiotensin II compared with ACE in human cardiovascular tissues. However, both ACE inhibitor and angiotensin II receptor blocker (ARB) lower systemic blood pressure, suggesting that ACE plays a dominant role in regulating angiotensin II formation. Although chymase converts angiotensin I to angiotensin II in the extracts of hearts and arteries, chymase-dependent angiotensin II formation may be irrelevant for the regulation of blood pressure in vivo (4). Chymase is synthesized as an inactive prochymase, and dipeptidylpeptidase I (DPPI) is necessary for chymase activation in the secretory granules (5). DPPI is a thiol proteinase with a $\mathrm{pH}$ optimum of 6.0 and the $\mathrm{pH}$ optimum of DPPI is consistent with its proposed function as a prochymase-activating enzyme, since the $\mathrm{pH}$ within the granule is regulated at $\mathrm{pH} 5.5$ (5). On the other hand, the optimum $\mathrm{pH}$ of chymase in human vascular tissues is between 7 and 9, and chymase has no enzymatic activity at pH 5.5 (2). Chymase shows enzymatic activity immediately upon release into the interstitial tissues after strong stimulation in cardiovascular tissues (4). Therefore, chymase may be released and have enzymatic activity only after the activation of mast cells in cardiovascular tissues.

Two rat chymases, rat mast cell protease (RMCP) I and RMCP II, both of which are expressed in mast cells, are known. Since these chymases only weakly convert angiotensin I to angiotensin II (6), it has been thought that rat cardiovascular tissues hardly contain angiotensin II-forming chymases. However, recently, Guo et al. (7) cloned a novel chymase, rat vascular chymase $(\mathrm{RVCH})$ from rat vascular smooth muscle cells (VSMCs). The cDNA encodes 247 amino acids and exhibits $74 \%$ and $80 \%$ homology for the amino acid sequence of RMCP I and RMCP II, respectively. RVCH, like human chymase, converts angiotensin I to angiotensin II (7). Over-expression of RVCH in VSMCs of transgenic mice induces systemic hypertension and vascular remodeling (8). In monocrotaline-induced pulmonary hypertensive $(\mathrm{PH})$ rats, $\mathrm{RVCH}$ mRNA and protein are increased in the pulmonary VSMCs, but it is unclear whether RVCH-dependent angio-

Abbreviations: ACE, angiotensin-converting enzyme; ARB, angiotensin II receptor blocker; DPPI, dipeptidylpeptidase I; LV, left ventricle; MWT, medial wall thickness; PH rats, pulmonary hypertensive rats; RMCP, rat mast cell protease; $\mathbf{R V C H}$, rat vascular chymase; $\mathbf{R V}$, right ventricle; VSMCs, vascular smooth muscle cells 
tensin II formation plays a pathophysiological role in vascular remodeling. In this study, we clarified the pathophysiological role of chymase-dependent angiotensin II formation in monocrotaline-induced $\mathrm{PH}$ rats.

\section{METHODS}

Materials. Monocrotaline were purchased from Sigma Chemical Co. (St. Louis, MO). An ARB candesartan was kindly provided by Takeda Chemical Industries (Osaka, Japan). An ACE inhibitor trandolaprilat was gifted from Hoechst Marion Roussel (Romainville, France). A chymase inhibitor NK3201 was gifted from Nippon Kayaku (Tokyo, Japan). NK3201 inhibited human, dog, rat and hamster chymases by $\mathrm{IC}_{50}$ at concentrations of 2.5, 1.2, 19 and $28 \mathrm{nM}$, respectively, but has no inhibitory activity to ACE, tryptase, thrombin, elastase, plasmin and plasminogen activator (9).

Hemodynamics and medial thickness index. A total of 34 male SpragueDawley rats aged $6 \mathrm{wk}$, weighing $268 \pm 4 \mathrm{~g}$ at the beginning of the experiment, were obtained from Japan SLC Inc. (Shizuoka, Japan). The rats were fed a regular hamster chow diet, had free access to tap water, and were housed in a temperature-, humidity-, and light-controlled room. The experimental procedures were done in accordance with the Guide for the Care and Use of Laboratory Animals (Animal Research Laboratory, Osaka Medical College).

We used two protocols. With the first protocol, we analyzed the pathophysiological role of chymase in the monocrotaline-induced $\mathrm{PH}$ rats; with the second, we evaluated the effect of an ARB in monocrotaline-induced PH rats.

To analyze the pathophysiological role of chymase in monocrotalineinduced PH rats, 8 rats were given monocrotaline $(60 \mathrm{mg} / \mathrm{kg}$, s.q.) (10). Four weeks after the injection, echocardiography and hemodynamic measurements were done under anesthesia. The rats were then killed with an overdose of sodium pentobarbital, and biochemical and histologic analyses were done. Six-age-matched rats received saline (s.q.) and were used as controls.

To evaluate the effect of an ARB in monocrotaline-induced $\mathrm{PH}$ rats, candesartan (10 mg/kg per day) or placebo (each group, $n=10)$ was given orally for $2 \mathrm{wk}$, starting $2 \mathrm{wk}$ after the monocrotaline injection.

Echocardiographic study. Four weeks after the injection of monocrotaline, echocardiography was done using an echocardiographic system (Nemio 30 , Toshiba, Japan) according to methods described previously (11). In brief, after IP injection of ketamine $\mathrm{HCl}(25$ to $50 \mathrm{mg} / \mathrm{kg}$ ) and xylazine (5 to $10 \mathrm{mg} / \mathrm{kg}$ ), measurements of the pulmonary acceleration time were taken and the Tei index was calculated using the pulsed Doppler mode $(12,13)$. The pulmonary acceleration time was measured from the time of onset of systolic flow to the time of onset of the peak pulmonary outflow velocity; a decrease in the acceleration time has been observed in monocrotaline-induced PH rats (12). The Tei index allows the evaluation of right ventricle (RV) systolic and diastolic functions and generally increases with PH, indicating RV dysfunction (13).

Hemodynamic measurement and tissue preparation. Four weeks after the injection of monocrotaline, the trachea was intubated for subsequent mechanical ventilation under anesthesia with ketamine $\mathrm{HCl}(25$ to $50 \mathrm{mg} / \mathrm{kg})$ and xylazine ( 5 to $10 \mathrm{mg} / \mathrm{kg}$ ). A left thoracotomy was performed through an incision in the fourth intercostal space. The pulmonary artery was isolated, and the pulmonary artery pressure was obtained by direct needle puncture of the pulmonary artery using a 22 gauge needle connected to a pressure transducer (TP-200T, Nihon Koden, Tokyo, Japan). A PE-10 catheter (Clay Adams, Parsippany, NJ) was inserted into the left femoral artery and was connected to a pressure transducer (TP-200T) to measure the systemic arterial blood pressure.

The rats were killed with an overdose of sodium pentobarbital $(100 \mathrm{mg} / \mathrm{kg})$ via the femoral artery. After the trachea and lungs were removed, the left lung was ligated, separated, weighed, and immediately frozen at $-80^{\circ} \mathrm{C}$ for use in the biochemical analysis. The right lung was preserved with $4 \%$ formaldehyde solution by airway gravity fixation and then used for histologic analysis. The $\mathrm{RV}$, left ventricle (LV), and septum were weighed separately to determine the ratio of the RV weight to the $\mathrm{LV}$ weight plus the septum weight as an index of RV hypertrophy (14).

Histologic analysis. The right lung lobes were fixed via the trachea using a $4 \%$ formaldehyde solution. Next, the whole lobe was cut into 5 sections for sampling. Each section was immersed in fixative overnight at $4^{\circ} \mathrm{C}$, and then processed and embedded in paraffin. Four- $\mu$ m-thick serial sections were stained with van Gieson stain. To assess pulmonary artery remodeling, the medial wall thickness (MWT) was calculated as $(2 \times$ medial thickness/ external diameter) $\times 100 \%(14)$. For all muscular arteries with an external diameter of 50 to $100 \mu \mathrm{m}$, the wall thickness of the media (that is, the distance between external and internal elastic laminae) was measured along the shortest curvature, and the MWT of the pulmonary arteries was measured in 10 muscular arteries per each section by two investigators who were blinded to treatment allocation.

Measurements of ace and chymase activities. ACE activities were measured by incubating the plasma or the tissue extracts for $30 \mathrm{~min}$ at $37^{\circ} \mathrm{C}$ with $5 \mathrm{mM}$ hippuril-His-Leu (Peptide Institute, Minoh, Japan) as the substrate when measuring ACE activity in $100 \mathrm{mM}$ phosphate buffer, $\mathrm{pH}$ 8.3, containing $300 \mathrm{mM} \mathrm{NaCl}$ (15). The enzyme reaction was terminated by the addition of $3 \%$ metaphosphoric acid (wt/vol). After centrifugation of the mixture, the supernatant was applied to an ODS reversed-phase column $(4.6 \mathrm{~mm} \times 25 \mathrm{~cm}$; Tosoh, Tokyo, Japan). Hippuric acid was detected by UV absorbance at $228 \mathrm{~nm}$. One unit of ACE activity was defined as the amount of enzyme that cleaved $1 \mu \mathrm{mol}$ hippuric acid/min.

Chymase activity was measured by incubating the tissue extracts for $30 \mathrm{~min}$ at $37^{\circ} \mathrm{C}$ with $5 \mathrm{mM}$ Suc-Ala-Ala-Pro-Phe-4-methylcoumaryl-7-amide (Peptide Institute) as a substrate for the measurement of chymase activity in $100 \mathrm{mM}$ Tris- $\mathrm{HCl}$ buffer, $\mathrm{pH} 8.5$, containing $200 \mathrm{mM} \mathrm{NaCl}$ (15). The enzyme reaction was terminated by the addition of $3 \%$ metaphosphoric acid (wt/vol). After centrifugation of the mixture, 7-amino-4methylcoumarin was measured by fluorophotometric determination (excitation $380 \mathrm{~nm}$; emission, $460 \mathrm{~nm}$ ). One unit of chymase activity was defined as the amount of enzyme that cleaved $1 \mu \mathrm{mol}$ 7-amino-4methylcoumarin/min.

Protein concentration was assayed with BCA Protein Assay Reagents (Pierce, Rockford, IL), using BSA as the standard.

Angiotensin II-forming activity and angiotensin ii concentration. Aliquots of the extract were incubated for $30 \mathrm{~min}$ at $37^{\circ} \mathrm{C}$ with $5 \mathrm{mM}$ angiotensin I in $10 \mathrm{mM}$ phosphate buffer, $\mathrm{pH} 7.4$, containing $150 \mathrm{mM} \mathrm{NaCl}$ (15). To study the effects of enzyme inhibitors, an ACE inhibitor, trandolaprilat $(1 \mu \mathrm{M})$, or a chymase inhibitor, NK3201 $(1 \mu \mathrm{M})$, was added, and pre-incubated for $10 \mathrm{~min}$ at $37^{\circ} \mathrm{C}$, followed by incubation for $30 \mathrm{~min}$ at $37^{\circ} \mathrm{C}$ with $5 \mathrm{mM}$ angiotensin I in $10 \mathrm{mM}$ phosphate buffer, $\mathrm{pH} 7.4$, containing $150 \mathrm{mM} \mathrm{NaCl}$ (15). At these concentrations, trandolaprilat and NK3201 completely inhibited ACE and chymase, respectively (9). The reaction was terminated by the addition of $15 \%$ trichloroacetic acid ( $\mathrm{wt} / \mathrm{vol})$, followed by centrifuging at $20,000 \mathrm{~g}$. The supernatant was applied to an ODS reversed-phase column $(4.6 \mathrm{~mm} \times 25 \mathrm{~cm}$; Tosoh). Angiotensin II was detected by UV absorbance at $218 \mathrm{~nm}$. One unit of angiotensin II-forming activity was defined as the amount of enzyme that formed $1 \mu \mathrm{mol}$ angiotensin II/min.

To measure the concentration of angiotensin II, the lungs were minced into small pieces, and then incubated overnight in ice-cold ethanol to extract angiotensin II (16). After the incubation, samples were centrifuged, and the supernatant was evaporated to remove ethanol. The extracts were then treated by shaking with diethylether, and the supernatant was again evaporated. Finally, the dried powder was dissolved in distilled water, and the angiotensin II concentration was determined by a high sensitivity enzyme immunoassay (Peninsula Laboratories, Inc., Belmont, CA, USA).

Reverse transcription (RT)-Pcr. The total RNA of the lung was extracted using TRIzol reagent (Life Technologies, Inc., Rockville, MD) and dissolved in $0.1 \%$ diethyl pyrocarbonate-treated water. RT to cDNA was accomplished by analyzing $5 \mu \mathrm{g}$ of the total RNA sample with SuperScript II reverse transcriptase and oligo(dT) $)_{12-18}$ primer (Invitrogen, Carlsbad, CA). The reaction was carried out in the presence of first-strand buffer, $1 \mathrm{mM}$ dNTPs, and $20 \mathrm{M} \mathrm{DTT}$, at $42^{\circ} \mathrm{C}$ for $50 \mathrm{~min}$. The PCR mixture contained $1 \mu \mathrm{L}$ of the cDNA reaction mixture, $20 \mathrm{pM}$ primers, PCR buffer, $0.4 \mathrm{mM}$ dNTPs, and $2.5 \mathrm{U} \mathrm{Taq}$ polymerase. The reaction was carried out with a RoboCycler (Stratagene, La Jolla, CA). The sequences of the oligonucleotide primers for PCR were as follows: RVCH sense primer, 5'-GAGGCCTGTAAAATCTATAGAC-3', and anti-sense primer, 5'-TGTGTATCTTTGAGAGCCTCAA-3', were used for the amplification of RVCH; ACE sense primer, $5^{\prime}$-CAGCTTCATCATCCAGTTCC-3' and anti-sense primer, 5'-CTAGGAAGAGCAGCACCCAC- $3^{\prime}$; and $\beta$-actin sense primer, $5^{\prime}$-CCAAGGCCAACCGCGAGAAGATGAC-3', and anti-sense primer, 5' -AGGGTACATGGTGGTGCCGCCAGAC- $3^{\prime}$, were used for the amplification of $\beta$-actin to calibrate sample loading $(7,17,18)$. The PCR products were separated by electrophoresis on $2 \%$ agarose gel stained with ethidium bromide and the samples were then visualized by UV trans-illumination. Polaroid photographs were scanned using Epson GT-9500 (Seiko Corp, Nagano, Japan), and the electrophoresis bands stained with ethidium bromide were analyzed using the public domain image analysis program from the National Institutes of Health Image software (version 1.61 available at rsb.info.nih.gov/nih-image). The density of an individual band was normalized to that of $\beta$-actin to correct for differences in samples.

Statistical methods. Data are expressed as mean \pm SEM. When two groups were compared, the differences were assessed by the unpaired $t$-test. Comparisons among three groups were made by one-way ANOVA followed by Bonferroni post hoc testing for multiple comparisons. Differences were considered significant only when the $P<0.05$. 


\section{RESULTS}

Analysis of the experimental model. The body weight of the control rats at the end of the experiment was $358 \pm 4 \mathrm{~g}$, and the body weight of the monocrotaline-induced $\mathrm{PH}$ rats was $303 \pm 8 \mathrm{~g}$; this difference was statistically significant.

On echocardiography, the acceleration time of pulmonary arterial flow in the monocrotaline-induced PH rats was significantly lower than in the control rats (Table 1). Moreover, the $\mathrm{RV}$ Tei index in the monocrotaline-induced $\mathrm{PH}$ rats was significantly higher than in the control rats. On hemodynamic analysis, there was no difference in the systolic arterial pressures between the control rats and the monocrotaline-induced $\mathrm{PH}$ rats (control rats, $105 \pm 4 \mathrm{~mm} \mathrm{Hg}$; monocrotaline-induced PH rats, $109 \pm 9 \mathrm{~mm} \mathrm{Hg}$ ). However, the systolic pulmonary arterial pressure in the monocrotaline-induced $\mathrm{PH}$ rats was higher than in the control rats (Table 1). An index of RV hypertrophy, the ratio of the RV weight to the LV weight plus septum weight, in the monocrotaline-induced $\mathrm{PH}$ rats was significantly greater than in the control rats (Table 1).

Typical photographs of arterioles stained with van Giesonstaining are shown in Fig. 1A. Hypertrophied arterioles were observed in the monocrotaline-induced PH rats, but not in the control rats. An index of pulmonary artery remodeling, the MWT of the arterioles, was $17.8 \pm 0.88$ in the monocrotalineinduced $\mathrm{PH}$ rats and $38.5 \pm 1.58$ in the control rats; this difference was statistically significant (Fig. 1B).

ACE activity in the monocrotaline-induced $\mathrm{PH}$ rats was significantly lower than in the control rats (Fig. 2A). In contrast, chymase activity was significantly higher in the monocrotaline-induced PH rats (Fig. $2 B$ ). Moreover, the angiotensin II concentration was significantly higher in the monocrotaline-induced $\mathrm{PH}$ rats than in the control rats (Fig. 2C). Using angiotensin I as a substrate, the angiotensin II-forming activity in lung extracts was significantly higher in the monocrotaline-induced $\mathrm{PH}$ rats than in the control rats (Fig. 3A). ACE inhibitor treatment reduced the angiotensin II-forming activity in the control rats by $96.6 \%$, but only by $4.7 \%$ in the monocrotaline-induced PH rats. In contrast, chymase inhibitor treatment reduced the angiotensin II-forming activity in the monocrotaline-induced $\mathrm{PH}$ rats by $95.1 \%$, but only by $3.3 \%$ in the control rats (Fig. $3 B$ ). The RVCH mRNA level in the monocrotaline-induced PH rats was significantly higher than in the control rats, but the ACE mRNA level in the monocrotaline-induced $\mathrm{PH}$ rats was significantly lower (Fig. 4).

Effects of an ARB in the monocrotaline-induced PH rats. There was no significant difference between the body weights
(A)
Control

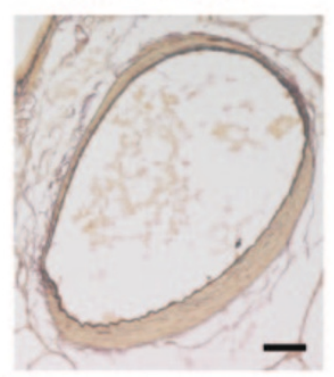

PH

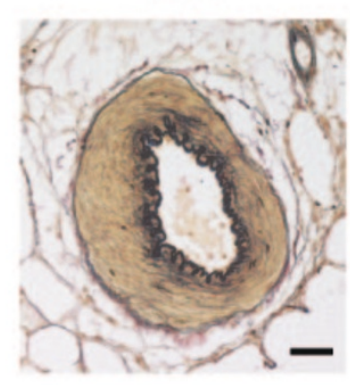

(B)

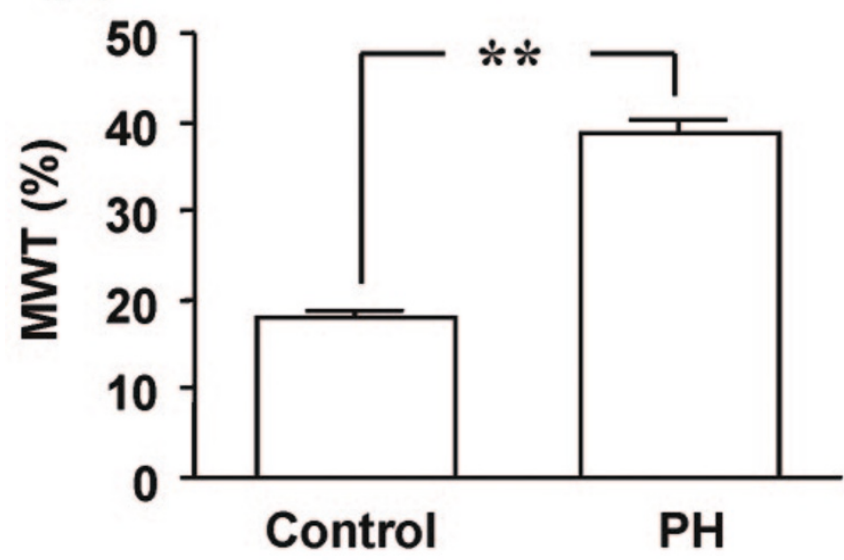

Figure 1. Typical photographs of pulmonary arterioles in control and monocrotaline-induced pulmonary hypertensive $(\mathrm{PH})$ rats $(A)$. MWT $(\%)$ of arterioles in control and monocrotaline-induced pulmonary hypertensive $(\mathrm{PH})$ rats $(B)$. Original magnification: $200 \times$. Scale bar in A, $10 \mu \mathrm{m}$. ** $p<0.01$.
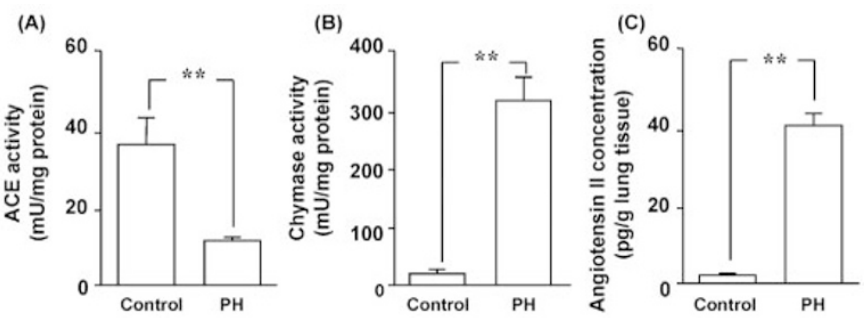

Figure 2. ACE activity $(A)$, chymase activity $(B)$ and angiotensin II concentration $(C)$ in lungs of control and monocrotaline-induced pulmonary hypertensive $(\mathrm{PH})$ rats. $* * p<0.01$.

of the monocrotaline-induced $\mathrm{PH}$ rats treated with a placebo $(303 \pm 6 \mathrm{~g})$ and those treated with an ARB $(298 \pm 5 \mathrm{~g})$.

The acceleration time of pulmonary arterial flow in the ARB-treated group was significantly increased compared with

Table 1. Characterization in control and monocrotaline-induced $\mathrm{PH}$ rats

\begin{tabular}{|c|c|c|c|c|}
\hline Animals & $\begin{array}{c}\text { Pulmonary } \\
\text { acceleration time } \\
(\mathrm{msec})\end{array}$ & RV Tei index & $\mathrm{RV} / \mathrm{LV}+\mathrm{S}$ ratio & $\begin{array}{l}\text { Pulmonary } \\
\text { arterial pressure } \\
(\mathrm{mmHg})\end{array}$ \\
\hline Control rats $(n=6)$ & $30 \pm 1.2$ & $0.41 \pm 0.03$ & $0.24 \pm 0.01$ & $23 \pm 0.86$ \\
\hline $\mathrm{PH}$ rats $(n=8)$ & $20 \pm 0.9 * *$ & $0.73 \pm 0.13 *$ & $0.40 \pm 0.03^{* *}$ & $49 \pm 2.96^{* *}$ \\
\hline
\end{tabular}

$\mathrm{PH}$ rats, pulmonary hypertensive rats; RV Tei index, right ventricular Tei index; RV/LV + S ratio, the ratio of right ventricle (RV) to left ventricle (LV) and septum.

$* p<0.05$ and $* * p<0.01$ versus control rats. 
(A)
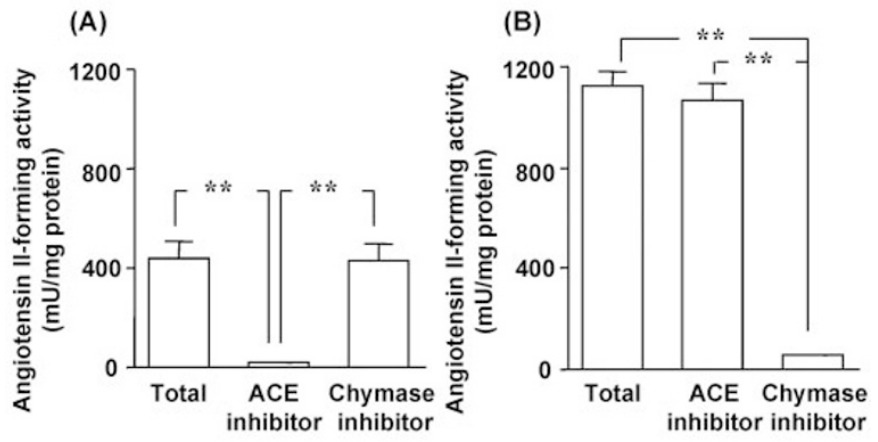

Figure 3. Lung angiotensin II-forming activity in the absence of an inhibitor (total), in the presence of an ACE inhibitor or a chymase inhibitor in control $(A)$ and monocrotaline-induced pulmonary hypertensive rats $(B)$. ** $p<0.01$.

(A)

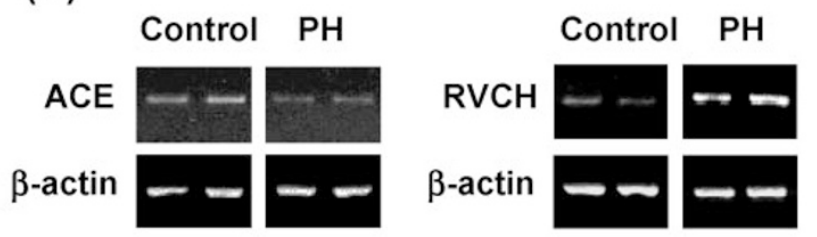

(B)
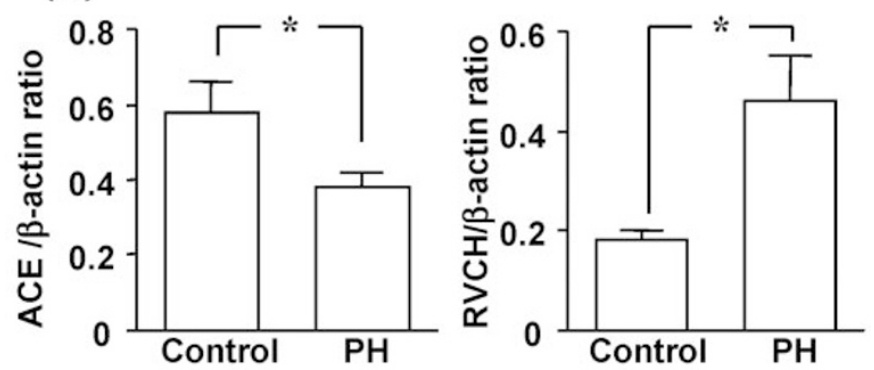

Figure 4. Typical photographs of ACE, RVCH, and $\beta$-actin expressions in lungs obtained from control and monocrotaline-induced pulmonary hypertensive $(\mathrm{PH})$ rats $(A)$. Ratios of ACE to $\beta$-actin expression or ratios of $\mathrm{RVCH}$ to $\beta$-actin expression in lungs obtained from control and monocrotaline-induced pulmonary hypertensive $(\mathrm{PH})$ rats $(B) .{ }^{*} p<0.05$.

the placebo-treated group (Fig. 5A). The RV Tei index in the ARB-treated group was significantly lower than in the placebo-treated group (Fig. $5 B$ ). The ratio of the RV weight to the LV weight plus the septum weight was significantly lower in the ARB-treated group than in the placebo-treated group (Fig. 5C). Although systolic systemic arterial pressure tended to be lower in the ARB-treated group than in the placebotreated group (placebo-treated group, $107 \pm 8 \mathrm{~mm} \mathrm{Hg}$; ARBtreated group, $94 \pm 4 \mathrm{~mm} \mathrm{Hg}$ ), this difference was not statistically significant $(p=0.15)$. On the other hand, a significant lowering of the systolic pulmonary arterial pressure was observed in the ARB-treated group (Fig. 6A). The MWT of the arterioles was also lower in the ARB-treated rats than in the placebo-treated rats (Fig. 6B).

\section{DISCUSSION}

Echocardiography is widely used to evaluate $\mathrm{PH}$ in clinical practice and in animal models $(13,19)$. The acceleration time of pulmonary arterial flow is used to evaluate RV dysfunction.

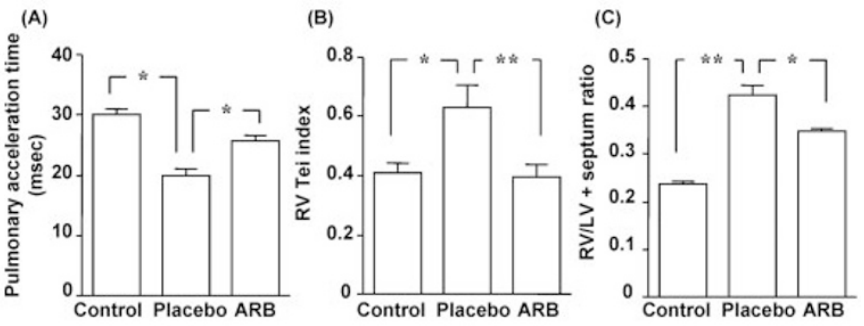

Figure 5. Effects of an ARB on the pulmonary acceleration time (A), RV Tei index $(B)$, and $\mathrm{RV} / \mathrm{LV}+$ septum ratio $(C)$ in monocrotaline-induced pulmonary hypertensive rats. ${ }^{*} p<0.05$ and ${ }^{*} p<0.01$.
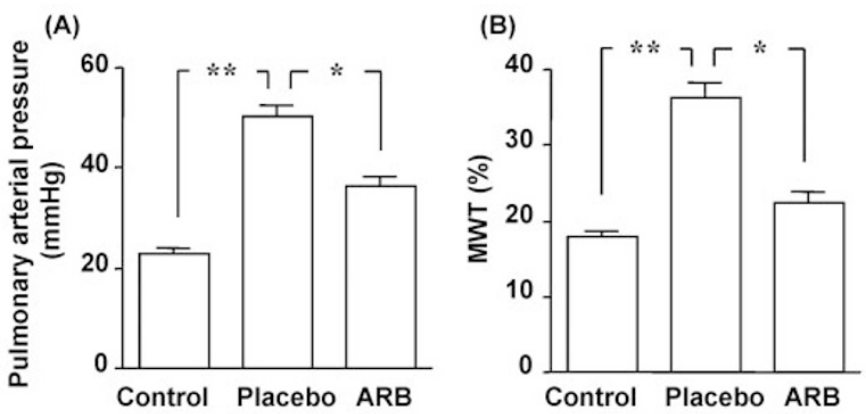

Figure 6. Effects of an ARB on the pulmonary arterial pressure $(A)$ and MWT $(B)$ in monocrotaline-induced pulmonary hypertensive rats. $* p<0.05$ and $* * p<0.01$.

The Tei index, which combines both systolic and diastolic parameters (13), provides a more detailed assessment of PHinduced RV dysfunction. In this study, both the acceleration time of pulmonary arterial flow and the RV Tei index had lower values in monocrotaline-induced PH rats than in control rats $4 \mathrm{wk}$ after monocrotaline injection. These results confirm that $\mathrm{RV}$ dysfunction was present in the monocrotaline-induced $\mathrm{PH}$ rats. When $\mathrm{PH}$ is present in both human and animal models, pulmonary arterial pressure increases due to increased pulmonary artery remodeling, particularly in the MWT of the arterioles. In our model, the arteriolar MWT was significantly higher in monocrotaline-induced $\mathrm{PH}$ rats than in control rats. An increase in the pulmonary arterial pressure is known to induce RV hypertrophy. We also observed a significant increase of RV hypertrophy (RV/LV plus septum ratio) in monocrotaline-induced $\mathrm{PH}$ rats. Thus, in monocrotalineinduced $\mathrm{PH}$ rats, progression in arteriolar thickness might increase pulmonary arterial pressure, resulting in RV hypertrophy and RV dysfunction.

Guo et al. (7) found a high level of RVCH expression in the medial layers of the pulmonary artery in monocrotalineinduced PH rats, but not in saline-treated control rats. In the present study, we observed a significant increase of $\mathrm{RVCH}$ mRNA levels in lung. In monocrotaline-induced PH rats, chymase activity was significantly increased compared with the controls. However, as previously reported, ACE activity was significantly reduced in the monocrotaline-induced $\mathrm{PH}$ rats (10). Furthermore, both angiotensin II-forming activity and angiotensin II concentration were significantly increased in monocrotaline-induced PH rats. However, angiotensin IIforming activity in the controls was almost completely inhib- 
ited by an ACE inhibitor, and its activity in monocrotalineinduced $\mathrm{PH}$ rats was almost completely inhibited by a chymase inhibitor. Such different effects of enzyme inhibitors suggest that angiotensin II-forming activity in the control rats was predominantly dependent on ACE, while, in the monocrotaline-induced $\mathrm{PH}$ rats, it was predominantly dependent on chymase. In other words, in the control rats, ACE carried the main function as an angiotensin II-forming enzyme, but chymase had this function in the monocrotaline-induced $\mathrm{PH}$ rats. In this study, the body weight tended to be lower in the ARB-treated group than in the placebo-treated group. Although there was no intermediate evaluation between the beginning and $4 \mathrm{wk}$ after the monocrotaline injection, it suggests that ARB treatment may not reduce direct monocrotaline toxicity. We also found that an ARB prevented the remodeling of arterioles and the occurrence of RV hypertrophy. All these findings suggest that RVCH-dependent angiotensin II formation may play an important role in the progression of monocrotaline-induced $\mathrm{PH}$.

Human chymase contributes to the formation of angiotensin II, which in turn, may be strongly correlated with pulmonary remodeling. Mitani et al. (20) reported that the number of chymase-containing mast cells in lung vasculature was clearly increased in $\mathrm{PH}$ patients compared with non-PH patients. This finding suggests that chymase is involved in the pulmonary vascular remodeling of $\mathrm{PH}$. Congenital heart diseases are associated with increased pulmonary arterial pressure, resulting in $\mathrm{PH}$ and subsequent pulmonary vascular diseases (21). Hamada et al. (22) investigated whether the number of chymase-containing mast cells in the pulmonary artery might contribute to the structural changes associated with $\mathrm{PH}$ in patients with congestive heart diseases; they found that there was a significant correlation between the number of chymasecontaining mast cells and pulmonary resistance. An increase in the number of chymase-containing mast cells may also play a possible role in the development of $\mathrm{PH}$ in patients with congenital heart diseases.

In general, it has been thought that, in cells other than mast cells, human chymase is expressed to only a small degree. However, some reports have shown that chymase is expressed in other cells. For example, using both immunohistochemical and in situ hybridization techniques, human chymase in the cytosolic granules of endothelial cells located in intramural capillaries and in some mesenchymal cells of the cardiac interstitium (23). Huang et al. (24) reported that the expression of human chymase in VSMCs was significantly higher in the diabetic kidney than in the normal kidney. Human chymase, like RVCH, may be expressed in human VSMCs and may contribute to angiotensin II formation in VSMCs.

In this study, lung ACE mRNA levels were significantly decreased in monocrotaline-induced PH rats. Previous investigators have reported that lung ACE activities were significantly decreased in monocrotaline-induced $\mathrm{PH}$ rats and have suggested that the reduction in lung ACE activity is a result rather than a cause of $\mathrm{PH}$ (25). However, ACE inhibitors have been shown to prevent monocrotaline-induced $\mathrm{PH}$ in rats $(26,27)$, while the effects of ARBs in monocrotaline-induced PH rats have not yet been determined. Cassiss et al. (28) reported that the ARB losartan failed to prevent monocrotaline-induced PH. Okada et al. (26) compared an ACE inhibitor, quinapril, with losartan, and though both agents were found to prevent $\mathrm{PH}$, the extent of inhibition with losartan was clearly weaker than with quinapril. From these results, they speculated that the mechanism of action of ACE inhibitors in PH might depend on the increase of bradykinin rather than on the reduction of angiotensin II formation $(26,28)$. On the other hand, the ARB irbesartan was found to significantly prevent PH (29), just as our study showed that candesartan prevented $\mathrm{PH}$. The discrepancies among ARBs may be related to the different character of each ARB (18). In this study, the upregulation of angiotensin II formation in the lung after monocrotaline injection might be dependent on the increase of $\mathrm{RVCH}$, but not ACE. Therefore, the combination of an ACE inhibitor and an ARB may be useful for increasing bradykinin accumulation by ACE (kininase II) inhibition and reducing angiotensin II formation by RVCH inhibition. This combination may be more effective in treating PH than monotherapy with either agent. Further studies are needed.

In the present study, our result suggests that RVCHdependent angiotensin II formation is involved in the development of monocrotaline-induced $\mathrm{PH}$ in rats.

\section{REFERENCES}

1. Urata H, Kinoshita A, Misono KS, Bumpus FM, Husain A 1990 Identification of a highly specific chymase as the major angiotensin II-forming enzyme in the human heart. J Biol Chem 265:22348-22357

2. Takai S, Shiota N, Sakaguchi M, Muraguchi H, Matsumura E, Miyazaki M 1997 Characterization of chymase from human vascular tissues. Clin Chim Acta 265:13-20

3. Okunishi H, Oka Y, Shiota N, Kawamoto T, Song K, Miyazaki M 1993 Marked species-difference in the vascular angiotensin II-forming pathways: humans versus rodents. Jpn J Pharmacol 62:207-210

4. Takai S, Jin D, Muramatsu M, Miyazaki M 2004 Chymase as a novel target for the prevention of vascular diseases. Trends Pharmacol Sci 25:518-522

5. Murakami M, Karnik SS, Husain A 1995 Human prochymase activation. A novel role for heparin in zymogen processing. J Biol Chem 270:2218-2223

6. Wintroub BU, Schechter NB, Lazarus GS, Kaempfer CE, Schwartz LB 1984 Angiotensin I conversion by human and rat chymotryptic proteinases. J Invest Dermatol 83:336-339

7. Guo C, Ju H, Leung D, Massaeli H, Shi M, Rabinovitch M 2001 A novel vascular smooth muscle chymase is upregulated in hypertensive rats. J Clin Invest 107:703715

8. Ju H, Gros R, You X, Tsang S, Husain M, Rabinovitch M 2001 Conditional and targeted overexpression of vascular chymase causes hypertension in transgenic mice. Proc Natl Acad Sci U S A 98:7469-7474

9. Takai S, Miyazaki M 2003 Application of a chymase inhibitor, NK3201, for prevention of vascular proliferation. Cardiovasc Drug Rev 21:185-198

10. Kay JM, Keane PM, Suyama KL, Gauthier D 1982 Angiotensin converting enzyme activity and evolution of pulmonary vascular disease in rats with monocrotaline pulmonary hypertension. Thorax 37:88-96

11. Jin D, Takai S, Yamada M, Sakaguchi M, Kamoshita K, Ishida K, Sukenaga Y, Miyazaki M 2003 Impact of chymase inhibitor on cardiac function and survival after myocardial infarction. Cardiovasc Res 60:413-420

12. Jones JE, Mendes L, Rudd MA, Russo G, Loscalzo J, Zhang YY 2002 Serial noninvasive assessment of progressive pulmonary hypertension in a rat model. Am J Physiol Heart Circ Physiol 283:H364-H371

13. Tei C, Dujardin KS, Hodge DO, Bailey KR, McGoon MD, Tajik AJ, Seward SB 1996 Doppler echocardiographic index for assessment of global right ventricular function. J Am Soc Echocardiogr 9:838-847

14. McMurtry MS, Bonnet S, Wu X, Dyck JR, Haromy A, Hashimoto K, Michelakis ED 2004 Dichloroacetate prevents and reverses pulmonary hypertension by inducing pulmonary artery smooth muscle cell apoptosis. Circ Res 95:830-840

15. Kirimura K, Takai S, Jin D, Muramatsu M, Kishi K, Yoshikawa K, Nakabayashi M, Mino Y, Kimura I, Miyazaki M 2005 Role of chymase-dependent angiotensin II formation in regulating blood pressure in spontaneously hypertensive rats. Hypertens Res 28:457-464

16. Muramatsu M, Katada J, Hayashi I, Majima M 2000 Chymase as a proangiogenic 
factor. A possible involvement of chymase-angiotensin-dependent pathway in the hamster sponge angiogenesis model. J Biol Chem 275:5545-5552

17. Lam SY, Leung PS 2003 Chronic hypoxia activates a local angiotensin-generating system in rat carotid body. Mol Cell Endocrinol 203:147-153

18. Takai S, Kirimura K, Jin D, Muramatsu M, Yoshikawa K, Mino Y, Miyazaki M 2005 Significance of angiotensin II receptor blocker lipophilicities and their protective effect against vascular remodeling. Hypertens Res 28:593-600

19. Jones JE, Walker JL, Song Y, Weiss N, Cardoso WV, Tuder RM, Loscalzo J, Zhang YY 2004 Effect of 5-lipoxygenase on the development of pulmonary hypertension in rats. Am J Physiol Heart Circ Physiol 286:H1775-H1784

20. Mitani Y, Ueda M, Maruyama K, Shimpo H, Kojima A, Matsumura M, Aoki K, Sakurai M 1999 Mast cell chymase in pulmonary hypertension. Thorax 54:88-90

21. Haworth SG 1987 Pulmonary vascular disease in ventricular septal defect: structural and functional correlations in lung biopsies from 85 patients, with outcome of intracardiac repair. J Pathol 152:157-168

22. Hamada H, Terai M, Kimura H, Hirano K, Oana S, Niimi H 1999 Increased expression of mast cell chymase in the lungs of patients with congenital heart disease associated with early pulmonary vascular disease. Am J Respir Crit Care Med 160:1303-1308

23. Urata H, Boehm KD, Philip A, Kinoshita A, Gabrovsek J, Bumpus FM, Husain A 1993 Cellular localization and regional distribution of an angiotensin II-forming chymase in the heart. J Clin Invest 91:1269-1281
24. Huang XR, Chen WY, Truong LD, Lan HY 2003 Chymase is upregulated in diabetic nephropathy: implications for an alternative pathway of angiotensin II-mediated diabetic renal and vascular disease. J Am Soc Nephrol 14:1738-1747

25. Molteni A, Ward WF, Ts'ao CH, Hinz JM 1989 Monocrotaline-induced cardiopulmonary injury in rats. Modification by the neutrophil elastase inhibitor SC39026. Biochem Pharmacol 38:2411-2419

26. Okada K, Bernstein ML, Zhang W, Schuster DP, Botney MD 1998 Angiotensinconverting enzyme inhibition delays pulmonary vascular neointimal formation. Am J Respir Crit Care Med 158:939-950

27. Kanno S, Wu YJ, Lee PC, Billiar TR, Ho C 2001 Angiotensin-converting enzyme inhibitor preserves $\mathrm{p} 21$ and endothelial nitric oxide synthase expression in monocrotaline-induced pulmonary arterial hypertension in rats. Circulation 104:945-950

28. Cassis LA, Rippetoe PE, Soltis EE, Painter DJ, Fitz R, Gillespie MN 1992 Angiotensin II and monocrotaline-induced pulmonary hypertension: effect of losar$\tan$ (DuP 753), a nonpeptide angiotensin type 1 receptor antagonist. J Pharmacol Exp Ther 262:1168-1172

29. Dalla Libera L, Ravara B, Angelini A, Rossini K, Sandri M, Thiene G, Battista Ambrosio G, Vescovo G 2001 Beneficial effects on skeletal muscle of the angiotensin II type 1 receptor blocker irbesartan in experimental heart failure. Circulation 103:2195-2200 